\title{
The Combination of Coagulation-Flocculation Method and the SCWO in the Waste Water Treatment Problems
}

\author{
Elmira Shakirovna Gayazova, Rustem Aytuganovich Usmanov, Farid Mukhamedovich Gumerov*, \\ Sergey Vladimirovich Friedland, Zufar Ibrahimovich Zaripov, \\ Farizan Rakibovich Gabitov, Rashid Zagitovich Musin \\ Kazan National Research University, Kazan, Russia \\ Email: gum@kstu.ru
}

Received July 18, 2013; revised August 22, 2013; accepted September 19, 2013

Academic Editor: Ilia Brondz ${ }^{1,2}$

${ }^{1}$ Department of Biosciences, University of Oslo, Oslo, Norway; ${ }^{2}$ R\&D Department, Jupiter Ltd.

Copyright (C) 2013 Elmira Shakirovna Gayazova et al. This is an open access article distributed under the Creative Commons Attribution License, which permits unrestricted use, distribution, and reproduction in any medium, provided the original work is properly cited.

\begin{abstract}
The influence of the degree of wastewater coagulation-flocculation and supercritical water oxidation (SCWO) methods is considered. The regularities of changes in the composition of the purity of the reagents used and the parameters of SCWO are established. Based on the results of chromatographic analysis of the effluent after washing the mass rape, it is found that the achievement of the required parameters is achieved by treatment with a combination of coagulationflocculation method and supercritical water oxidation (SCWO). The necessity of combining techniques is insufficient oxidation in SCWO lignin conducted at $\mathrm{T}=400^{\circ} \mathrm{C}$ and $\mathrm{P}=25 \mathrm{MPa}, \mathrm{T}=500^{\circ} \mathrm{C}$ and $\mathrm{P}=30 \mathrm{MPa}$. Effluent treatment of process of styrene and propylene oxide "Nizhnekamskneftekhim" conducted by the SCWO, using an oxidant $\left(\mathrm{H}_{2} \mathrm{O}_{2}\right)$, and without an oxidant showed the possibility of cleaning without the use of an oxidizing agent in the process parameters $\mathrm{T}=500^{\circ} \mathrm{C}, \mathrm{P}=30 \mathrm{MPa}$.
\end{abstract}

Keywords: Supercritical Water Oxidation (SCWO); Wastewater Treatment; Production of Pulp; Coagulation; Flocculation; Chemical Axigen Demand (COD); Chromato Graphic Analysis

\section{Introduction}

In this paper, we have considered the possibility for supercritical water oxidation (SCWO) treatment of wastewater containing components, which are difficultly oxidizing.

Oxidative methods are increasingly used in wastewater treatment. Most often ozone, chlorine, sodium hypochlorite, hydrogen peroxide, at least—Fenton's reagent are used as oxidants. Each of these reagents has its pros and cons, so the introduction of advanced oxidation processes in water treatment practices using new oxidants is very important.

In recent years, a new method of industrial wastewater treatment is rapidly developing, based on the use of the supercritical water as an oxidant $\left(\mathrm{T}>374^{\circ} \mathrm{C}, \mathrm{P}>22.1\right.$ $\mathrm{MPa}$ ) [1]. When the water is in supercritical conditions, it behaves like a nonpolar solvent unlimitedly dissolving organic substances and gases, but not dissolving the mineral salts. In SCW almost complete utilization of in-

\footnotetext{
"Corresponding author.
}

dustrial waste water in a reasonable time is achieved by varying the temperature and concentration of the reactants. The completeness and speed of reactions in supercritical water (SCW) are provided by a molecular dispersion of the reactants. The kinetics and mechanisms of chemical reactions in SCW depends on the temperature and pressure (density) of the medium. Thus, even a slight change in pressure SCW is accompanied by a significant change in the density, essential for diffusion, viscosity, and dielectric properties of the solvent medium.

The SCWO process goes with the release of heat if the initial reaction mixture contains enough organic substances $(10 \%-25 \%)[2]$.

\section{Experimental}

Waste water after rapeseed mass washing that contains hardly degradable polymer components (lignin, cellulose Table 1) was selected as the object of the study.

The composition of the industrial wastewater after washing is shown in Table 1. 
Table 1. The composition of the industrial wastewater after rapeseed mass washing.

\begin{tabular}{cc}
\hline \multicolumn{1}{c}{ Ingredients } & Organic part \\
\hline Alkali lignin & \\
Lignin dissolved & $4000 \mathrm{~kg}$ of pulp \\
\hline Hydroxy acids and lactones & 120 \\
Resin and fatty acids & 300 \\
Acetic Acid & 90 \\
Formic Acid & 60 \\
Polysaccharides & 30 \\
Methanol & 20 \\
Nitrogenous compounds & 8 \\
Methyl-sulfides compounds & 5 \\
& 2 \\
$\mathrm{NaOH}$, bound to organic substances & \\
$\mathrm{NaOH}_{\text {free }}$ & 210 \\
$\mathrm{Na}_{2} \mathrm{~S}$ & 105 \\
$\mathrm{Na}_{2} \mathrm{CO}_{3}$ & 50 \\
$\mathrm{Na}_{2} \mathrm{SO}_{4}$ & 50 \\
Other sodium salts & 45 \\
Other minerals & 50 \\
$\mathrm{pH}_{\mathrm{COD} \text { mgO/L. }}$ & 20 \\
& $10-12$ \\
\hline
\end{tabular}

The main characteristic of organic compounds' content reducing was chosen the COD method of analysis for as an integrated efficiency index of the process. The experiment was conducted on the installation (Figure 1), which allows to realize the of rape wastewater SCWO process in periodic mode at pressures up to $60 \mathrm{MPa}$ and temperatures up to $800 \mathrm{~K}$.

The possibility for the treatment of the wastewater described above was investigated using following oxidants: hydrogen peroxide, manganese oxide (II), potassium perchlorate and without oxidant.

The amount of oxidant was calculated using the wastewater composition and COD values.

Reaction cell filled with "rape" drains, water and oxidizer in the calculated quantities. The cell is equipped with a high-pressure valve that allows the discharge of the vapor phase after the completion of the process. The over-heat of muffle furnace at the preliminary stage (to $550^{\circ} \mathrm{C}-650^{\circ} \mathrm{C}$ ) allows a quick attainment of the water's supercritical condition in the autoclave. By the end of the process (after 10 minutes) the cell was taken out of the furnace and cooled, cell's content was analyzed for COD $[3,4]$. The chromatographic analysis was also carried out.

Earlier studies for wastewater treatment using coagulation and flocculation methods showed that processes remove mostly compounds with a relatively high molecular weight (polymeric structures) [5].

Thus, to increase the efficiency of wastewater treatment on the manufactures considered the combining of

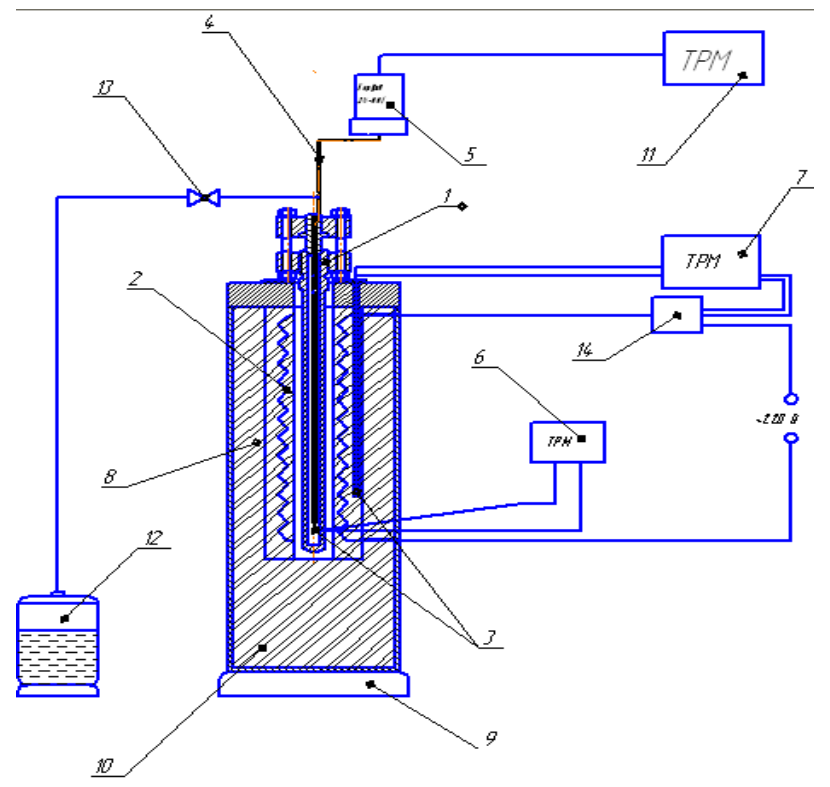

Figure 1. The scheme for the SCWO carrying high-temperature apparatus : 1 , reaction cell, 2 , muffle furnace, 3 , the hot junction of the thermocouple, 4 , chamber of pressure sensor, 5, pressure sensor PD100-DI, 6,7,11, secondary devices TPM 101 for pressure and temperature, 8, electric heater, 9, furnace's stand, 10, insulation, 12, a collector of water, 13 , high pressure valve.

coagulation-flocculation methods and SCWO can be used. The main thing for the wastewater treatment experiment by the coagulation method was the use of $30 \%$ iron sulphate (II, III) solutions, at an optimal $\mathrm{pH}$ range: for $\mathrm{Fe}(\mathrm{OH})_{2}-8.510 .5$, while for $\mathrm{Fe}(\mathrm{OH})_{3}$ from 4 to 6 and 8 to 10 [6].

Reagent solutions were added in the effluent liquid at a concentration range from 0.5 to $15 \mathrm{~g} / 1$ in terms of dry matter. After the coagulation treatment, coagulum was filtered with a filter fabric and the filtrate was analyzed for COD, $\mathrm{pH}$ and light transmittance. Physicochemical parameters of the filtrates after coagulation treatment are shown in Table 2.

To improve the deposition of sediment, experiments were performed with $0.1 \%$ flocculant solutions of different brands and different activity: anionic flocculant "Praestol 2640" (Component company manufacture: "water Him" Ltd.), cationic flocculant mark "Praestol 611" (Component company manufacture: "waterHim" Ltd.) and natural starch (Component company manufacture: "AO Reahim" Ltd. GOST 10163-76-Reagents. Soluble starch. TU) flocculant.

Coagulant solution $\mathrm{Fe}_{2}\left(\mathrm{SO}_{4}\right)_{3}$ with concentration of 5 $\mathrm{g} / \mathrm{L}$ is added in the liquid effluent. Samples are mixed thoroughly for 2 minutes, and then the flocculant solution with concentration of 1 to $3 \mathrm{mg} / \mathrm{L}$ is injected. Then the samples' values of COD, $\mathrm{pH}$ and light transmittance are taken. Physicochemical parameters of the wastewater after the coagulant and flocculant treatment are shown in Table 3. 
Table 2. Physicochemical parameters after the coagulant wastewater treatment $(\mathrm{CW})$.

\begin{tabular}{|c|c|c|c|}
\hline \multirow[t]{2}{*}{$\begin{array}{c}\text { Coagulant } \\
\text { concentration, } \\
\mathrm{g} / \mathrm{L}\end{array}$} & \multicolumn{3}{|c|}{$\begin{array}{c}\mathrm{FeSO}_{4} / \mathrm{Fe}_{2}\left(\mathrm{SO}_{4}\right)_{3}(\mathrm{Component} \text { company } \\
\text { manufacturer: Closed Joint Stock Company } \\
\text { "Prominvest",Iron (II) sulphate 7-water, } \\
\mathrm{FeSO}_{4} \text { x } 7 \mathrm{H}_{2} \mathrm{O} \text {, Clean, GOST 4148-78, } \\
\text { Iron (III) sulphate, 9-water (clean), } \\
\mathrm{Fe}_{2}\left(\mathrm{SO}_{4}\right)_{3} \times 9 \mathrm{H}_{2} \mathrm{O} \text {, GOST 6981-94) }\end{array}$} \\
\hline & $\mathrm{COD} \mathrm{mgO} / \mathrm{L}$ & $\mathrm{pH}$ & $\begin{array}{c}\text { Light transmittance } \\
(1=5 \mathrm{~mm}, \\
\lambda=750 \mathrm{~nm})\end{array}$ \\
\hline Initial CW & 16140 & 12.5 & 5 \\
\hline 0.5 & $14384 / 16000$ & $12.3 / 11.03$ & $23 / 30$ \\
\hline 1 & $14215 / 16000$ & $11.07 / 9.96$ & $15 / 28$ \\
\hline 3 & $9424 / 6103$ & $5.72 / 3.85$ & $82 / 89$ \\
\hline 5 & $9920 / 6033$ & $5.56 / 2.68$ & $82 / 72$ \\
\hline 10 & $7440 / 8071$ & $5.46 / 1.95$ & $71 / 79$ \\
\hline 15 & $9920 / 7283$ & $5.42 / 1.63$ & $61 / 81$ \\
\hline
\end{tabular}

Table 3. Physicochemical properties after the wastewater treatment using coagulant $\mathrm{FeSO}_{4} / \mathrm{Fe}_{2}\left(\mathrm{SO}_{4}\right)_{3}$ (Component company manufacturer: Closed Joint Stock Company "Prominvest”, Iron (II) sulphate-7-water, $\mathrm{FeSO}_{4} \times 7 \mathrm{H}_{2} \mathrm{O}$, Clean, GOST 4148-78,Iron (III) sulphate, 9-water (clean), $\mathrm{Fe}_{2}\left(\mathrm{SO}_{4}\right)_{3}$ $\times 9 \mathrm{H}_{2} \mathrm{O}$, GOST 6981-94) and flocculants.

\begin{tabular}{|c|c|c|c|c|}
\hline Flocculant & $\begin{array}{c}\text { Dose of } \\
\text { flocculant, } \\
\mathrm{mg} / \mathrm{L}\end{array}$ & $\begin{array}{c}\mathrm{pH} \\
\mathrm{FeSO}_{4} / \\
\mathrm{Fe}_{2}\left(\mathrm{SO}_{4}\right)_{3}\end{array}$ & $\begin{array}{c}\mathrm{COD} \\
\mathrm{mgO} / \mathrm{L} \\
\mathrm{FeSO}_{4} / \\
\mathrm{Fe}_{2}\left(\mathrm{SO}_{4}\right)_{3}\end{array}$ & $\begin{array}{c}\text { Light } \\
\text { transmittance } \\
(1=5 \mathrm{~mm}, \\
\lambda=750 \mathrm{~nm}) \\
\mathrm{FeSO}_{4} / \mathrm{Fe}_{2}\left(\mathrm{SO}_{4}\right)_{3}\end{array}$ \\
\hline $\begin{array}{c}\text { Praestol } 2640 \\
\text { (Component }\end{array}$ & 1 & $4.82 / 2.66$ & $8875 / 8203$ & $72 / 33$ \\
\hline $\begin{array}{c}\text { company } \\
\text { manufacture: }\end{array}$ & 2 & $4.81 / 2.55$ & $9076 / 7812$ & $71 / 24$ \\
\hline “waterHim" Ltd.) & 3 & $4,9 / 2,57$ & $8838 / 7812$ & $75 / 27$ \\
\hline $\begin{array}{l}\text { Praestol } 611 \\
\text { (Component }\end{array}$ & 1 & $4.51 / 2.57$ & $9172 / 7422$ & $60 / 56$ \\
\hline $\begin{array}{l}\text { company } \\
\text { manufacture: }\end{array}$ & 2 & $4.76 / 2.58$ & $9273 / 8203$ & $72 / 67$ \\
\hline "waterHim" Ltd.) & 3 & $5.04 / 2.61$ & $9076 / 7422$ & $76 / 72$ \\
\hline $\begin{array}{c}\text { Starch (Component } \\
\text { company } \\
\text { manufacture: }\end{array}$ & & & & \\
\hline $\begin{array}{c}\text { “AO Reahim” Ltd. } \\
\text { GOST 10163-76 - } \\
\text { Reagents. Soluble } \\
\text { starch. TU) }\end{array}$ & 1 & $4.76 / 2.60$ & $8683 / 8203$ & $75 / 70$ \\
\hline
\end{tabular}

\section{Results and Discussion}

We have studied two possible methods of wastewater treatment of pulp from rape straw. Works with the original waste water, as well as with previously untreated water by coagulants and flocculants carried out.

The results obtained in experiments using SCWO waste liquid source are reflected in Figures 2(a)-(c) show a decrease in (COD), but do not achieve the desired performance values needed for biological purification.

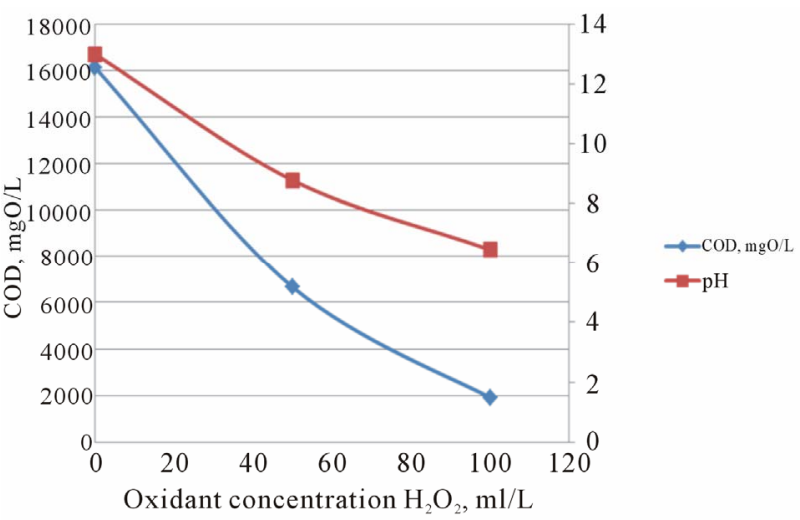

(a)

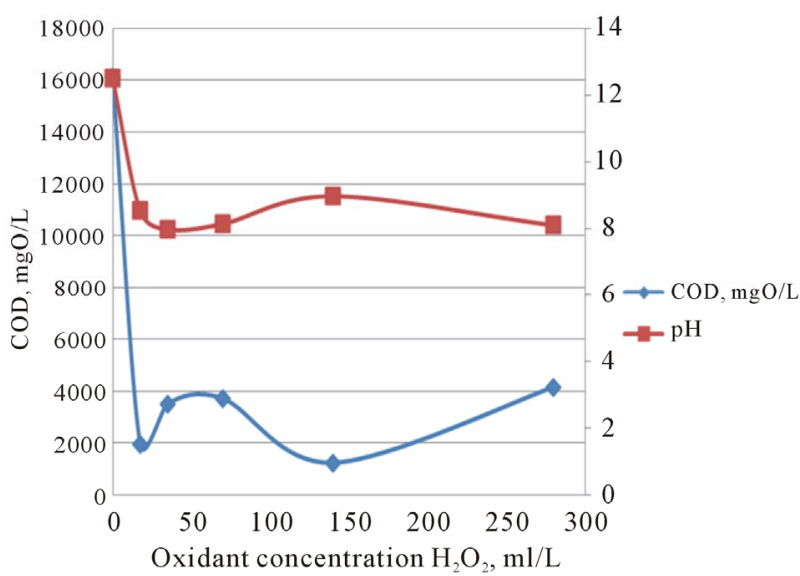

(b)

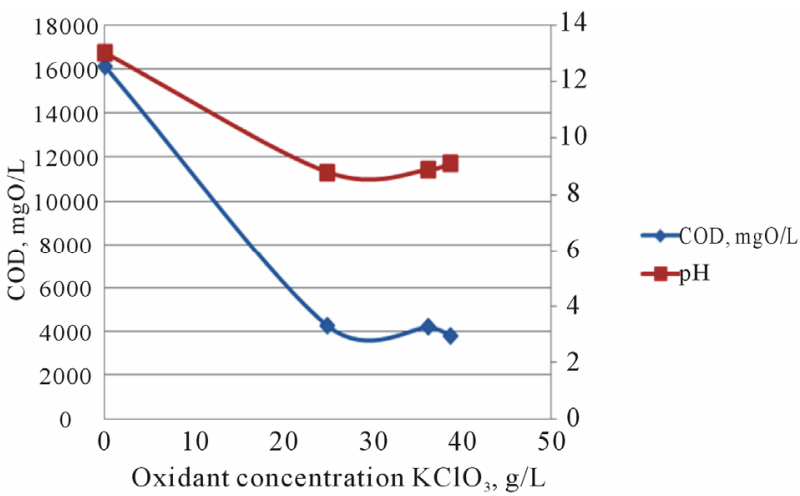

(c)

Figure 2. (a) Schedule of changes the value of COD and $\mathrm{pH}$ from concentration of oxidant $\mathrm{H}_{2} \mathrm{O}_{2}$ (Component company manufacture: Himprom Novocheboksarsk, hydrogen peroxide, $\mathrm{H}_{2} \mathrm{O}_{2}(30 \%)$ at $\mathrm{T}=400^{\circ} \mathrm{C}, \mathrm{p}=24 \mathrm{MPa}$, CODpre $=$ $16140 \mathrm{mgO} / \mathrm{L}$; (b) Schedule of changes the value of COD and $\mathrm{pH}$ from concentration of oxidant $\mathrm{MnO}_{2}$ (Component company manufacture: STP TU COMP 1-251-10, MANGANESE DIOXIDE, $\mathrm{MnO}_{2}$,clean) at $\mathrm{T}=400^{\circ} \mathrm{C}, \mathrm{p}=24$ MPa, CODpre = $16140 \mathrm{mgO} / \mathrm{L}$; (c) Schedule of changes the value of $\mathrm{COD}$ and $\mathrm{pH}$ from concentration of oxidant $\mathrm{KClO}_{3}$ (Component company manufacture: "Soda-Chlorate" Ltd. Potassium chlorate, TU 6-18-24-84, clean) at $\mathrm{T}=400^{\circ} \mathrm{C}, \mathrm{p}=$ $24 \mathrm{MPa}$, CODpre $=16140 \mathrm{mgO} / \mathrm{L}$. 
In previously conducted studies to analyze the completeness of organics removal were held chromatography-mass spectrometric studies of the decomposition of lignin-water-hydrogen peroxide by number of Japanese scientists, which shows that the water-soluble part contains the monomeric and dimeric lignin degradation products. Analysis using GC-MS was found 31 products [7]. These results clearly showed that the soluble portion includes various monomeric and dimeric compounds resulting from the destruction and elimination of ester bonds lignin propyl radical [2-4].

Reported studies indicate that more complete oxidation are monomeric components, polymers reacting oxidation SCWO conditions formed hydroxyl, carbonyl and carboxyl groups without causing extensive oxidation to gaseous components $\left(\mathrm{CO}_{2}, \mathrm{CO}\right)$ [8].

As a result discussed above, it would be logical to combine the process of SCWO by coagulation-flocculation treatment in the first stage.

From the data in Table 3 can be seen that the best cleaning when $\mathrm{FeSO}_{4}$ (Component company manufacturer: Closed Joint Stock Company "Prominvest", Iron (II) sulphate-7-water, $\mathrm{FeSO}_{4}$ × $7 \mathrm{H}_{2} \mathrm{O}$, Clean, GOST 4148- 78, Iron (III) sulphate, 9-water (clean), $\mathrm{Fe}_{2}\left(\mathrm{SO}_{4}\right)_{3} \mathrm{X}$ $9 \mathrm{H}_{2} \mathrm{O}$, GOST 6981-94) used as a coagulant observed using this reagent in an amount of $10 \mathrm{~g} / \mathrm{L}$. In the case of application of $\mathrm{Fe}_{2}\left(\mathrm{SO}_{4}\right)_{3}$ best cleaning result is achieved by using a reagent concentration of $5 \mathrm{~g} / \mathrm{L}$. Increasing the concentration of the reagent solution is to move the waste water from acidic to alkaline medium at a $\mathrm{pH}$ lower than 6 is dissolved precipitate, and consequently leads to an increase of COD values.

As it is shown in the Table $\mathbf{4}$ data, the best clarification of the wastewater occurs with the use of starch (Component company manufacture: "AO Reahim" Ltd. GOST 10163-76 - Reagents Soluble starch. TU) as flocculating additive with a concentration of $1-2 \mathrm{mg} / \mathrm{L}$.

The efficiency of wastewater from pulp rape straw significant influence raw water $\mathrm{pH}$ : at values close to neutral, the degree of purification considerably lower than in

Table 4. The composition of industrial wastewater production of styrene and propylene oxide of "Nizhnekamskneftekhim".

\begin{tabular}{cc}
\hline ingredients & $\%$ mass. \\
\hline ethylbenzene & 2.5 \\
acetophenone & 1 \\
methylphenylcarbinol & 6.5 \\
phenol & 2.5 \\
propylene glycol & 12 \\
molybdenum & 0.2 \\
other & 35.3 \\
COD & $225000 \mathrm{mg} \mathrm{O} / \mathrm{L}$ \\
\hline
\end{tabular}

the processing water with $\mathrm{pH}>8$. This effect is achieved when higher dosages coagulant flocculation occurs slowly precipitate bad precipitated and the supernatant liquid is present finely dispersed suspension. This problem can be solved by increasing the initial $\mathrm{pH}$ of the waste water to an optimum.

In general, waste water treatment, presented in this paper is the best iron sulfate (III). Use of this reagent results in a well-structured and floc sludge settling and effective brightening of treated water is not required to neutralize the water. Ferrous sulfate (II) also allows to obtain satisfactory results, but at doses of $1.5-2$ times larger.

After the pre-treatment of wastewater by coagulationflocculation methods, waste liquid was subjected to the same treatment in the North Caucasus Military District installation. Processing results are presented in Figures 3(a)-(c).

The liquid portion after the presented experiments was analyzed by gas chromatography-mass spectrometry. The study was conducted on the device (DFS) Thermo Electron Corporation (Germany). The method of ionization: electron impact. The energy of the ionizing electrons was $70 \mathrm{eV}$, the ion source temperature $290^{\circ} \mathrm{C}$. Used capillary column ID-BPX5, length-60 $\mathrm{m}$, diameter-0.32-mm. Carrier Gas-helium. Processing mass spectral data was performed using the program "Xcalibur". Purity of the sample prior to entering the device diluted in chromatographically pure acetone at a concentration about $1 \%$ wt.

Conditions for obtaining chromatograms:

1. The injector temperature $-280^{\circ} \mathrm{C}$, the flow division (split) $-1: 20$.

2. Warming up the column was carried out in the program mode: Initial temperature- $60^{\circ} \mathrm{C}(3 \mathrm{~min})$, heating rate $10^{\circ} \mathrm{C} / \mathrm{min}$, final temperature $-280^{\circ} \mathrm{C}(30 \mathrm{~min}$. $)$

3 . The flow of carrier gas through the column $-2 \mathrm{~mL} /$ $\min$

4. Temperature communication devices with a mass spectrometer- $280^{\circ} \mathrm{C}$.

5. The sample volume of $0.1 \mathrm{~mL}$.

Below is a gas chromatography-mass spectrometry analysis of the products SCWO Figures 4(a) and (b).

Analyzing data of chromatogram Figure $3 \mathrm{a}$, can be concluded that the above substances are degradation products of lignin not removed by coagulation and flocculation in particular (2,3-dimethyl 2-cyclopentenone-1, acetophenone, biphenyl, 4,5-dimethyl-1,3-dioxane-4-methanol), fatty acid esters are believed to be the reaction products of fatty and resin acids present in the composition of the initial waste water.

According to Figure 4(b) also detected decomposition products of lignin and complex esters of polyhydric acids, but their number is found in a smaller proportion, therefore, decreases the amount of organic matter in the sam- 


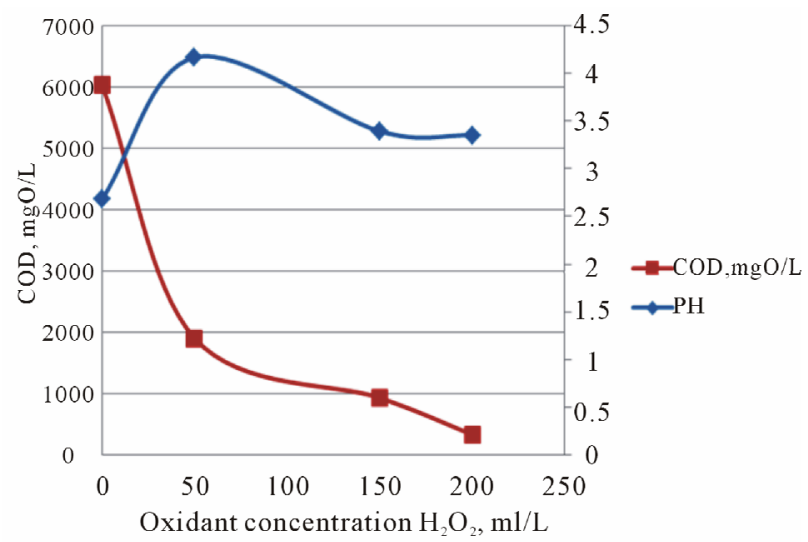

(a)

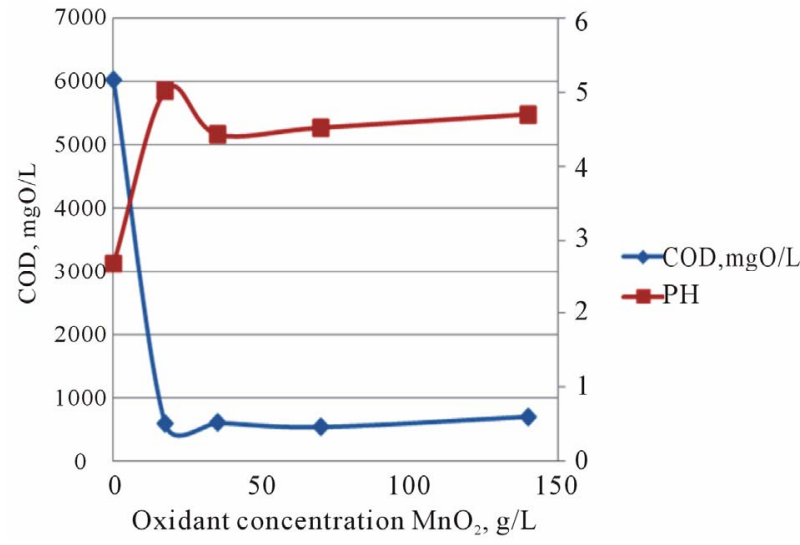

(b)

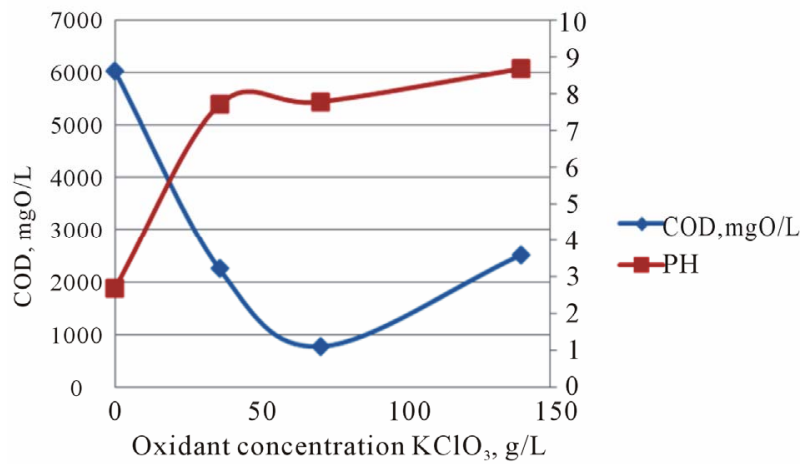

(c)

Figure 3. (a) Schedule of changes the value of COD and pH from concentration of oxidant $\mathrm{H}_{2} \mathrm{O}_{2}$ (Component company manufacture: Himprom Novocheboksarsk, hydrogen peroxide, $\mathrm{H}_{2} \mathrm{O}_{2}(30 \%)$, OST 301-02-205-99 amended. 1) at $\mathrm{T}=$ $400^{\circ} \mathrm{C}$, p = $24 \mathrm{MPa}$, CODpre $=6033 \mathrm{mgO} / \mathrm{L}$; (b) Schedule of changes the value of $\mathrm{COD}$ and $\mathrm{pH}$ from concentration of oxidant $\mathrm{MnO}_{2}$ (Component company manufacture: STP TU COMP 1-251-10, MANGANESE DIOXIDE, $\mathrm{MnO}_{2}$, clean) at $\mathrm{T}=400^{\circ} \mathrm{C}, \mathrm{p}=24 \mathrm{MPa}$, CODpre $=6033 \mathrm{mg} \mathrm{O} / \mathrm{L}$; (c) Schedule changes the value of $\mathrm{COD}$ and $\mathrm{pH}$ from concentration of oxidant $\mathrm{KClO}_{3}$ (Component company manufacture: "Soda-Chlorate" Ltd. Potassium chlorate, TU 6-1824-84, clean) at $\mathrm{T}=400^{\circ} \mathrm{C}, \mathrm{p}=24 \mathrm{MPa}, \mathrm{CODpre}=6033 \mathrm{mg}$ O/L.

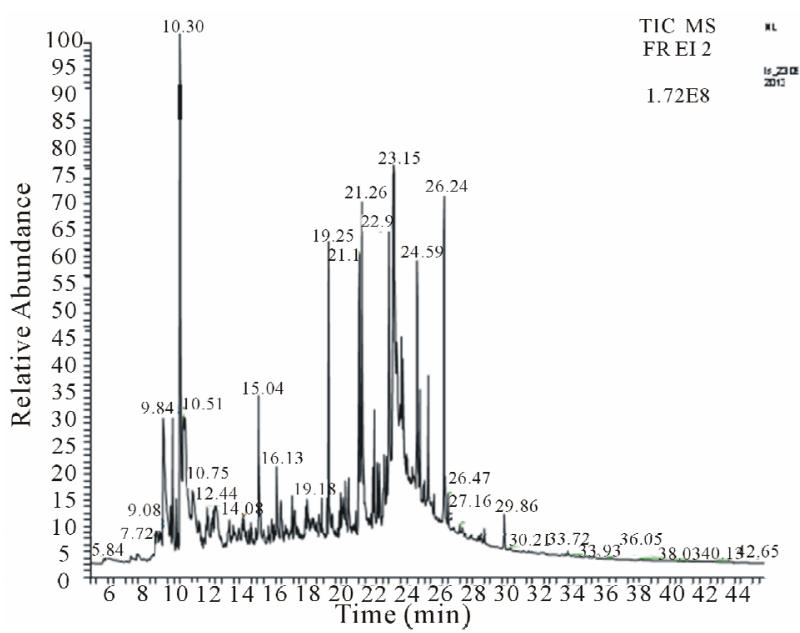

(a)

\begin{tabular}{cccc}
\hline $\begin{array}{c}\text { Retention Relative } \\
\text { time }\end{array}$ & content, $\%$ & Name & Formula \\
\hline 9.29 & 12.08 & phenol & $\mathrm{C}_{6} \mathrm{H}_{6} \mathrm{O}$ \\
9.84 & 3.56 & 2,3 - dimethyl 2 - cyclopentenone - 1 & $\mathrm{C}_{7} \mathrm{H}_{10} \mathrm{O}$ \\
10.3 & 16.97 & acetophenone & $\mathrm{C}_{8} \mathrm{H}_{8} \mathrm{O}$ \\
15.04 & 5.76 & biphenyl & $\mathrm{C}_{12} \mathrm{H}_{10}$ \\
16.13 & 1.47 & 4,5 - dimethyl-1, 3 - dioxane - 4 - & $\mathrm{C}_{7} \mathrm{H}_{14} \mathrm{O}_{3}$ \\
19.25 & 6.36 & Tetradecanoic acid ethyl ester & $\mathrm{C}_{16} \mathrm{H}_{32} \mathrm{O}_{2}$ \\
21.11 & 6.06 & Ethyl 9 geksadekenoic acid & $\mathrm{C}_{18} \mathrm{H}_{34} \mathrm{O}_{2}$ \\
21.26 & 7 & Hexadecanoic acid ethyl ester & $\mathrm{C}_{18} \mathrm{H}_{36} \mathrm{O}_{2}$ \\
22.9 & 8.58 & Ethyl 9 oktadekenoic acid & $\mathrm{C}_{20} \mathrm{H}_{38} \mathrm{O}_{2}$ \\
23.21 & 11.02 & Cis-13 oktadekenoic acid & $\mathrm{C}_{18} \mathrm{H}_{34} \mathrm{O}_{2}$ \\
24.59 & 7.49 & Methyl cis -11- eicosenoic acid & $\mathrm{C}_{21} \mathrm{H}_{40} \mathrm{O}_{2}$ \\
24.76 & 1.45 & Methyl 19-eicosenoic acid methyl & $\mathrm{C}_{22} \mathrm{H}_{44} \mathrm{O}_{2}$ \\
25.26 & 2.22 & Methyl cis 11.14 - eicosenoic acid & $\mathrm{C}_{21} \mathrm{H}_{38} \mathrm{O}_{2}$ \\
26.24 & 8.91 & 2- dipropilpetiloic phthalate & $\mathrm{C}_{24} \mathrm{H}_{38} \mathrm{O}_{4}$ \\
29.86 & 1.07 & H- tetrakozan & $\mathrm{C}_{24} \mathrm{H}_{50}$ \\
\hline
\end{tabular}

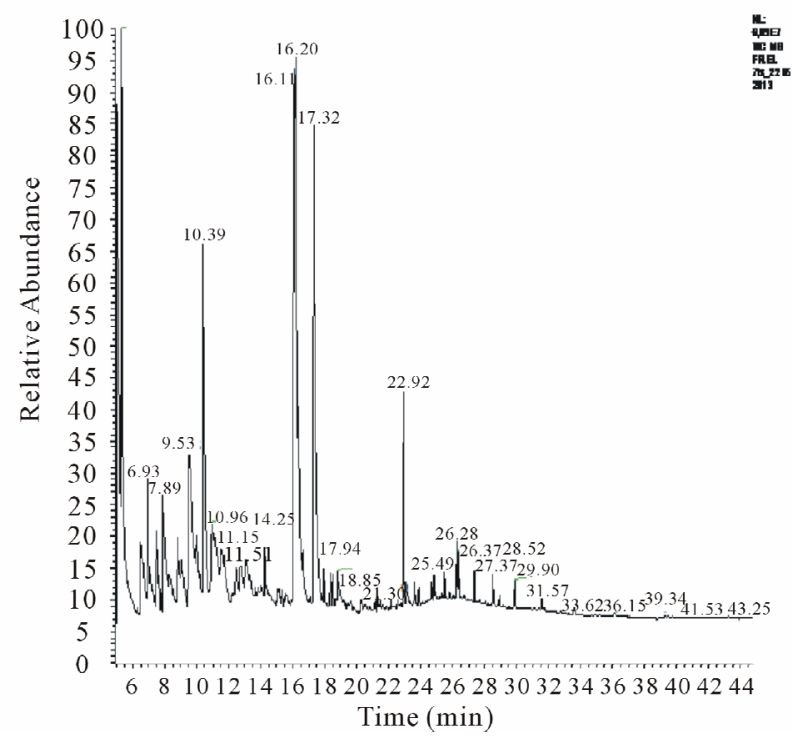

(b) 


\begin{tabular}{cccc}
\hline $\begin{array}{c}\text { Retention } \\
\text { time }\end{array}$ & $\begin{array}{c}\text { Relative } \\
\text { content, } \%\end{array}$ & Name & Formula \\
\hline 5.29 & 11.93 & Butyl acetate & $\mathrm{C}_{6} \mathrm{H}_{12} \mathrm{O}_{2}$ \\
6.46 & 3.11 & furfural & $\mathrm{C}_{5} \mathrm{H}_{4} \mathrm{O}_{2}$ \\
9.53 & 13.6 & phenol & $\mathrm{C}_{6} \mathrm{H}_{6} \mathrm{O}$ \\
10.39 & 14.63 & acetophenone & $\mathrm{C}_{8} \mathrm{H}_{8} \mathrm{O}$ \\
16.2 & 25.04 & 4,5 - dimethyl-1, 3 - dioxane - 4 - & $\mathrm{C}_{7} \mathrm{H}_{14} \mathrm{O}_{3}$ \\
& methanol & $\mathrm{C}_{11} \mathrm{H}_{13} \mathrm{NO}_{2}$ \\
17.32 & 25.87 & 3,5 - diacetillyutidin & $\mathrm{C}_{20} \mathrm{H}_{38} \mathrm{O}_{2}$ \\
22.92 & 2.85 & Ethyl 9 oktadekenoic acid & $\mathrm{C}_{20} \mathrm{H}_{42}$ \\
25.49 & 0.43 & eicosane & $\mathrm{C}_{20} \mathrm{H}_{42}$ \\
26.37 & 0.48 & 2 - metilnonadekan & $\mathrm{C}_{26} \mathrm{H}_{54}$ \\
28.52 & 0.47 & 11 - (1-ethyl-propyl) geneykozan & $\mathrm{C}_{21} \mathrm{H}_{44}$ \\
31.57 & 0.48 & $2,6,10,15$ - metilgeptadekan & \\
\hline
\end{tabular}

Figure 4. (a) SCWO chromatogram, hydrogen peroxide concentration $200 \mathrm{ml} / \mathrm{L}$ using as oxidate. (b) SCWO chromatogram, MnO2(Component company manufacture: STP TU COMP 1-251-10, MANGANESE DIOXIDE, $\mathrm{MnO}_{2}$, clean) concentration $70 \mathrm{~g} / \mathrm{L}$ using as oxidate.

ples represented by a significant decrease in the values of COD Figure 3(b).

In the case of wastewater from pulp rape straw promising is the use of manganese dioxide as represented by the above dependences (3(a), 3(b), 3(c)) can be seen a significant reduction in COD values, and therefore better cleaning liquid waste. The undeniable advantage is also the possibility of regeneration is represented by the oxide.

After the process in the cell pellet is formed, a mixture of manganese oxides in a lower oxidation state $\left(\mathrm{Mn}_{2} \mathrm{O}_{3}\right.$, $\mathrm{Mn}_{3} \mathrm{O}_{4}$ ), which can then be regenerated for re-use in the cleaning cycle [9].

Regeneration of the manganese oxide can be produced upon standing in air or $\mathrm{O}_{2}$ atmosphere at a temperature above $300^{\circ} \mathrm{C}[10]$.

Next, we have studied the possibility of wastewater containing no polymer structures wastewater production of styrene and propylene oxide of "Nizhnekamskneftekhim" compositions are given in Table 4.

In consequence of the fact that the presented items contain no polymeric component as compared to the above described drain pulp. Consideration was given to the data cleansing water only using the method of SCWO [11]. However, since a large values of COD, the reaction time was increased to 30 minutes. Also were built according to changes in the values of COD from the different process parameters SCWO data presented in Figures 5(a) and (b).

Analyzing of depending concluded that this type of waste water purification is possible without using an oxidizing agent at the process parameters $\mathrm{T}=500^{\circ} \mathrm{C}, \mathrm{P}=30$ MPa (Figure 5(b)), this solution is economically feasible as excluded cost oxidant.

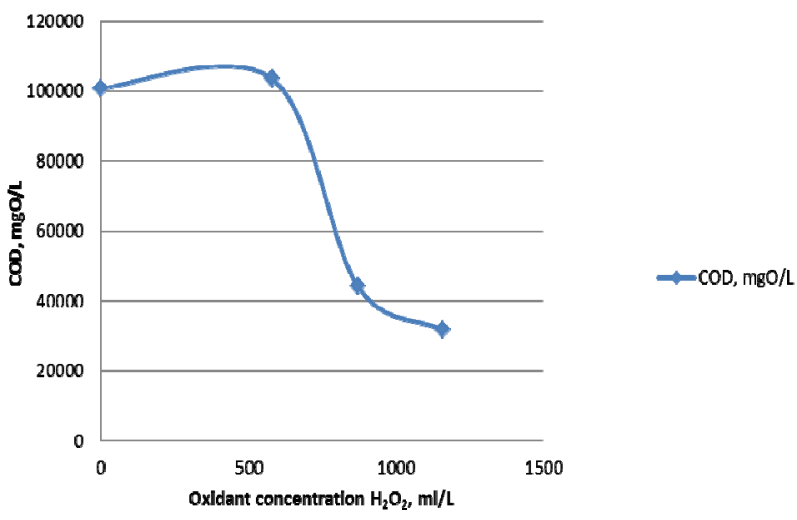

(a)

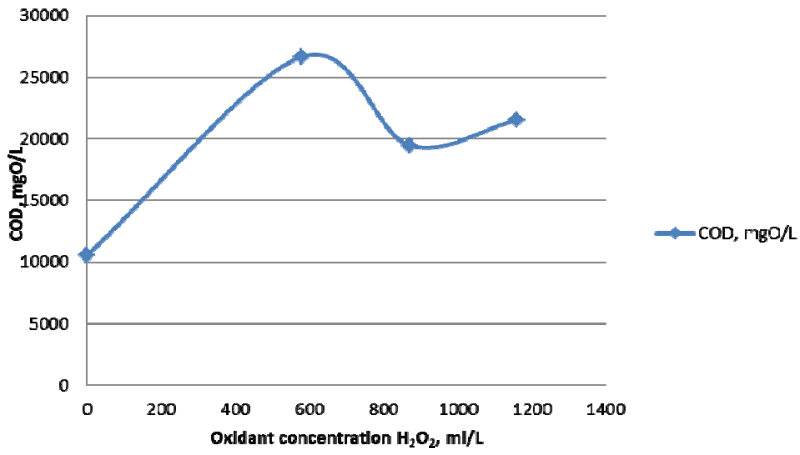

(b)

Figure 5. (a) Schedule of changes in the value of COD and concentration of oxidant $\mathrm{H}_{2} \mathrm{O}_{2}$ (Component company manufacture: HimpromNovocheboksarsk, hydrogen peroxide, $\mathrm{H}_{2} \mathrm{O}_{2}(30 \%)$, OST 301-02-205-99 amended. 1) $\left(\mathrm{T}=400^{\circ} \mathrm{C}\right.$, p = $24 \mathrm{MPa}$ ); (b) Schedule of changes in the value of COD and concentration of oxidant $\mathrm{H}_{2} \mathrm{O}_{2}$ (Component company manufacture: HimpromNovocheboksarsk, hydrogen peroxide, $\mathrm{H}_{2} \mathrm{O}_{2}(30 \%)$, OST 301-02-205-99 amended. 1) $(\mathrm{T}=$ $\left.500^{\circ} \mathrm{C}, \mathrm{p}=30 \mathrm{MPa}\right)$.

\section{Conclusion}

Conducted research on wastewater treatment of various industrial effluents found that to improve the quality of treatment of waste washing rape weight required a combination of the two methods of treatment-coagulationflocculation method and supercritical water oxidation (SCWO) needed. Purification of effluents of industrial production of styrene and propylene oxide by SCWO process is available under the process parameters $\mathrm{T}=$ $500^{\circ} \mathrm{C}, \mathrm{P}=30 \mathrm{MPa}$ without using an oxidizing agent.

\section{REFERENCES}

[1] F. M. Gumerov, "Sub- and Supercritical Fluids in Polymer Processing," FEN, Kazan, 2000, p. 328.

[2] A. A. Vostrikovs, D. Dubov and S. A. Psarov, "The Effect of Thermal Explosion in Supercritical Water," Technical Physics Letters, Vol. 27, No. 20, 2001, pp. 7-13. doi:10.1134/1.1414551 
[3] S. V. Yakovlev, J. A. Karelin, Y. M. Tender and V. Voronov, "Process Wastewater Treatment," Stroyizdat, Moskow, 1979, p. 320.

[4] E. J. Buslaeva, K. G. Kravchuk, Y. F. Kargin and S. P. Gubin, "Reactions of $\mathrm{MnO}_{2}, \mathrm{Mn}_{2} \mathrm{O}_{3}, \alpha-\mathrm{Bi}_{2} \mathrm{O}_{3}$, and $\mathrm{Bi}_{12} \mathrm{Ti}_{1-\mathrm{x}} \mathrm{Mn}_{\mathrm{x}} \mathrm{O}_{20}$ with Supercritical Isopropanol," Inorganic materials, Vol. 38, No. 6, 2002, pp. 706-710. doi:10.1023/A:1015813502466

[5] S. Timonin, "Engineering and Environment Book," Publisher N. Botchkareva, Kaluga, 2003, p. 884.

[6] S. Saka and K. Ehara, "Biomass Research for Post-Petrochemistry by Supercritical Water," Proceedings of the International Symposium on Highly Efficient Use of Energy and Reduction of Its Environmental Impact, Special Panel Session on Biomass Utilization, Osaka, 22 January 2002.

[7] J. Tsujino, H. Kawamoto and S. Saka, "Reactivity of Lignin in Supercritical Methanol Studied with Various Lignin Model Compounds," Journal of Wood Science, Vol. 49, No. 2, 2003, pp. 158-165. doi: $10.1007 / \mathrm{s} 100860300025$
[8] D. Takada, K. Ehara and S. Saka, "Gas Chroma Tographic and Mass Spectrometric (GC-MS) Analysis of Lignin-Derivedproducts from Cryptomeria Japonica Treated in Supercritical Water," Journal of Wood Science, Vol. 50, No. 3, 2004, pp. 253-259. doi:10.1007/s10086-003-0562-6

[9] K. Ehara, D. Takada and S. Saka, "GC-MS and IR Spectroscopic Analyses of the Lignin-Derived Products from Softwood and Hardwood Treated in Supercritical Water," Journal of Wood Science, Vol. 51, No. 3, 2005, pp. 256261. doi:10.1007/s10086-004-0653-z

[10] M. E. Posin, "Technology of Mineral Salts (Fertilizers, Pesticides, Industrial Salts, Oxides and Acids)," Publishing House of the "Chemistry", 1974, p. 792.

[11] F. M. Gumerov, R. A. Kayumov, R. A. Usmanov, A. A Sagdeev, I. Sh. Abdullin and R. F. Sharafeev, "Waste Management in Propylene Epoxidation Process with the Use of Supercritical Fluid Media," American Journal of Analytical Chemistry, Vol. 3, No. 12A, 2012, pp. 950957. 